\title{
PENGARUH KEHARMONISAN KELUARGA, PERGAULAN TEMAN SEBAYA DAN INTENSITAS BERMAIN GAME ON LINE BERTEMA KEKERASAN TERHADAP PERILAKU AGRESIF SISWA DI MTSN 8 SLEMAN TAHUN PELAJARAN 2018-2019
}

\author{
Wiwin Subriyani Rahayu \\ Program Pasca Sarjana \\ Universitas Muhammadiyah Yogyakarta \\ E-mail: wiwinnice 76@yahoo.com
}

\begin{abstract}
Abstrak
Penelitian ini menguji empat hipotesis: pertama, ada pengaruh signifikan Keharmonisan Keluarga terhadap perilaku Agresif siswa, kedua, ada pengaruh signifikan Pergaulan Teman Sebaya terhadap perilaku agresif siswa, ketiga, ada pengaruh signifikan Intensitas bermain game online bertema kekerasan terhadap perilaku agresif siswa dan ke-empat, ada pengaruh signifikan dari Keharmonisan keluarga, Pergaulan teman Sebaya dan Intensitas bermain game online bertema kekerasan secara bersama-sama terhadap Perilaku agresif siswa. Populasi dalam penelitian ini adalah seluruh siswa MTs N 8 Sleman yang berjumlah 587 siswa. Sampel dalam penelitian ini berjumlah 110 siswa. Teknik Pengumpulan Data dilakukan menggunakan Angket diperkaya dengan Dokumentasi, Wawancara dan Observasi. Hasil penelitian ini menunjukkan bahwa : Hasil pengujian hipotesis 1 menunjukkan nilai t hitung $>\mathrm{t}$ tabel $(2,545>1,98)$ dan signifikansi $(0,012<0,050)$. Hal ini berarti Semakin tinggi keharmonisan keluarga siswa, akan diikuti semakin rendahnya perilaku agresif siswa. Hasil pengujian hipotesis 2 menunjukkan nilai $\mathrm{t}$ hitung $>\mathrm{t}$ table $(2,836>1,98)$ dan signifikansi $(0,005<0,050)$. Artinya semakin kondusif pergaulan teman sebaya dari siswa tersebut akan memiliki peluang untuk tidak berperilaku agresif. Hasil pengujian hipotesis 3 menunjukkan nilai $t$ hitung $>\mathrm{t}$ tabel $(3,683>1,98)$ dan signifikansi $(0,010<0,050)$ berarti Intensitas bermain game Online bertema kekerasan berpengaruh signifikan terhadap Perilaku agresif siswa sebesar 33,6\%.

Kata kunci : keharmonisan keluarga, pergaulan teman sebaya, perilaku agresif
\end{abstract}

\begin{abstract}
This study examines four hypotheses: first, there is a significant influence of Family Harmony on students' Aggressive behavior, second, there is a significant influence of Peer Associations on aggressive behavior of students, third, there is a significant influence Intensity of playing online games on the theme of violence towards aggressive behavior of students and fourth, there is a significant influence of family harmony, peer relations and the intensity of playing online games with the theme of violence together against aggressive behavior of students. The population in this study were all students of MTs N 8 Sleman, totaling 587 students. The sample in this study amounted to 110 students. Data collection techniques are carried out using questionnaires enriched with documentation, interviews and observations. The results of this study indicate that: Hypothesis 1 test results show the value of $t$ arithmetic $>t$ table (2.545> $1.98)$ and significance $(0.012<0.050)$. This means that the higher the harmony of students' families, the lower the aggressive behavior of students will be followed. Hypothesis 2 test results show the value of $t$ arithmetic $>t$ table (2.836> 1.98) and significance $(0.005<0.050)$. This means that the more conducive peer interaction of students will have the opportunity not to behave aggressively. Hypothesis 3 test results show the value of $t$ arithmetic $>t$ table (3.683> $1.98)$ and significance $(0.010<0.050)$ means the intensity of playing online games with a violent effect significantly influence the aggressive behavior of students by $33.6 \%$.
\end{abstract}

Keywords: family harmony, peer relations, aggressive behavior

\section{Info Artikel}

Diterima Februari 2020, disetujui Maret 2020, diterbitkan Juni 2020 


\section{PENDAHULUAN}

Menurut Undang-Undang Nomor 20 Tahun 2003 tentang Sistem Pendidikan Nasional (selanjutnya disebut UU Sisdiknas), pendidikan adalah usaha sadar dan terencana untuk mewujudkan suasana belajar dan proses pembelajaran agar peserta didik secara aktif mengembangkan potensi dirinya untuk memiliki kekuatan spiritual keagamaan, pengendalian diri, kepribadian, kecerdasan, akhlak muliadan keterampilan, yang diperlukan dirinya, masyarakat, bangsa, dan negara. Seorang peserta didik tidak bisa dinilai dengan ukuran kecerdasan intelektual semata, mengabaikan adab dan karakter.

Oleh sebab itulah, pendidikan di Indonesia pada umumnya harus mampu menghasilkan insan-insan yang tidak hanya cerdas (sesuai klasifikasi kecerdasan yang bisa diperdebatkan), melainkan juga berakhlak mulia. Hasil need assessment program Bimbingan dan konseling di MTs N 8 Sleman tahun pelajaran 2017-2018 menunjukkan peningkatan gejala agresifitas pada siswa dari tahun ke tahun yang signifikan. Dari berbagai proses pemecahan masalah, dapat ditarik kesimpulan sementara bahwa adatiga faktor utama yang menyebabkan agresifitas, yakni (1) pengaruh tingkat keharmonisan keluarga yang rendah, (2) pergaulan teman yang tidak kondusif dan (3) game online bertema kekerasan.

Dari uraian diatas,bisa diketahui sejumlah permasalahan, meliputi:

1. Perilaku agresif pelajar yang kian meningkat dan luas butuh penanganan serius dan efektif.

2. Tak stabilnya kelas (class instability)akibat beberapa pelajar berperilaku menyimpang, melanggar tata tertib, mengganggu teman dan membuat keresahan.

3. Mayoritas siswa pelaku agresifitas berasal dari keluarga yang kurang harmonis (broken home).

4. Mayoritas siswa pelaku agresifitas punya jaringan pertemanan dengan siswa-siswa yang punya kesamaan karakter, sikap,kebiasaan dan/atau kondisi.

5. Siswa-siswa yang terdeteksi mengalami permasalahan perilaku agresif memiliki kecenderungan meniru adegan kekerasan dari kebiasaan bermain game online bertema kekerasan. 


\section{METODE PENELITIAN}

Sesuai dengan tujuan penelitian untuk mengetahui ada tidaknya pengaruh keharmonisan keluarga, pergaulan teman sebaya dan intensitas bermain game on line bertema kekerasan terhadap perilaku agresif siswa di MTsN 8 Sleman tahun pelajaran 2018-2019, maka penelitian ini merupakan penelitian kuantitatif. Penelitian yang dilakukan ini adalah termasuk jenis penelitian kuantitatif dengan pendekatan korelasional. Arikunto (2010:247) menjelaskan bahwa penelitian korelasional adalah penelitian yang dimaksudkan untuk mengetahui ada tidaknya hubungan antara dua atau beberapa variabel. Dengan teknik korelasi, seorang peneliti dapat mengetahui hubungan variasi antara sebuah variabel dengan variabel yang lain. Besar atau tingginya hubungan tersebut dinyatakan dalam bentuk koefisien korelasi. Semakin besar koefisien korelasi, berarti semakin erat hubungan yang terjadi. Sedangkan Teknik analisis data menggunakan Uji normalitas, Uji linieritas dan analisis regresi berganda. Populasi dalam penelitian ini adalah seluruh siswa MTs N 8 Sleman yang berjumlah 587 siswa dengan sampel 110 siswa. Instrumen penelitian menggunakan angket.

\section{HASIL DAN PEMBAHASAN}

\section{Pengaruh Keharmonisan Keluarga terhadap Perilaku Agresif.}

Dari hasil uji T membuktikan bahwa walaupun variabel keharmonisan keluarga hanya mempunyai pengaruh sebesar $20,4 \%$, namun besarnya pengaruh tersebut sangat berarti, karena setelah dibuktikan secara statistik dengan uji T terbukti bahwa nilai Thitung $(2,545)$ lebih besar dari T-tabel $(1,98)$. Nilai $\mathrm{p}$ (peluang ralat) $=0,012<$ taraf signifikansi $=0,05$. Hasil tersebut menunjukkan bahwa keharmonisan keluarga dapat mempengaruhi perilaku agresif siswa di MTs Negeri 8 Sleman.

\section{Pengaruh Pergaulan Teman Sebaya terhadap Perilaku Agresif}

Karena t-hitung $=2,836>\mathrm{t}$-tabel $=1,98$, dan $\mathrm{p}=0,005<0,05(5 \%)$, maka disimpulkan bahwa ada pengaruh positif dan signifikan antara variabel Pergaulan Teman Sebaya terhadap Perilaku Agresif. Dari hasil uji $\mathrm{T}$ membuktikan bahwa walaupun variabel pergaulan teman sebaya hanya mempunyai pengaruh sebesar $26,4 \%$, namun besarnya pengaruh tersebut sangat berarti, karena setelah dibuktikan secara statistik dengan uji $\mathrm{T}$ terbukti bahwa nilai T-hitung $(2,836)$ lebih besar dari T-tabel 
$(1,98)$. Nilai $\mathrm{p}$ (peluang ralat) $=0,005<$ taraf signifikansi $=0,05$, yang mempunyai arti bahwa meskipun memiliki pengaruh yang kecil tetapi ternyata variabel pergaulan teman sebaya mempunyai pengaruh yang positif dan signifikan terhadap perilaku agresif siswa di MTs Negeri 8 Sleman.

\section{Pengaruh Intensitas Bermain Game Online terhadap Perilaku Agresif}

Dari hasil uji T membuktikan bahwa walaupun variabel intensitas bermain game online bertema kekerasan hanya mempunyai pengaruh sebesar 33,6\%, namun besarnya pengaruh tersebut sangat berarti, karena setelah dibuktikan secara statistik dengan uji $\mathrm{T}$ terbukti bahwa nilai T-hitung $(3,683)$ lebih besar dari T-tabel $(1,98)$. Nilai $\mathrm{p}$ (peluang ralat $)=0,010<$ taraf signifikansi $=0,05$. Hasil ini mempunyai arti bahwa meskipun memiliki pengaruh yang kecil tetapi ternyata variabel intensitas bermain game online bertema kekerasan mempunyai pengaruh yang positif dan signifikan terhadap perilaku agresif siswa di MTs Negeri 8 Sleman. Dengan demikian hipotesis yang ketiga terbukti kebenarannya.

Pengaruh Keharmonisan Keluarga, Pergaulan Teman Sebaya, dan Intensitas Bermain Game Online bertema Kekerasan terhadap Perilaku Agresif.

Koefisien determinasi (R-Square) sebesar 0,352 yang menunjukkan bahwa 35,2\% variasi perilaku agresif siswa di MTs Negeri 8 Sleman ditentukan oleh adanya faktor keharmonisan keluarga, pergaulan teman sebaya, dan intensitas bermain game online bertema kekerasan. Sedangkan sisanya sebesar 64,8\% variasi perilaku agresif siswa di MTs Negeri 8 Sleman ditentukan oleh faktor yang lain di luar variabel yang diteliti.

Hasil analisis regresi diperoleh nilai Fhitung sebesar 19,231, sedangkan Ftabel sebesar 2,690. Dengan demikian hipotesis yang keempat terbukti kebenarannya.

\section{KESIMPULAN}

Dari pembahasan dan uraian pada bagian sebelumnya, maka dapat ditarik kesimpulan sebagai berikut :

1. Berdasarkan analisis terbukti bahwa variabel keharmonisan keluarga berpengaruh secara positif dan signifikan terhadap perilaku agresif siswa di MTs Negeri 8 
Sleman. Hal ini dapat diartikan bahwa keharmonisan keluarga yang dimiliki siswa suatu madrasah dapat mempengaruhi banyak sedikitnya perilaku agresif siswa di Madrasah tersebut.

2. Berdasarkan analisis terbukti bahwa variabel pergaulan teman sebaya berpengaruh secara positif dan signifikan terhadap perilaku agresif siswa di MTs Negeri 8 Sleman. Hal ini berarti bahwa, Intensitas pergaulan teman sebaya suatu Madrasah dapat mempengaruhi banyak sedikitnya perilaku agresif siswa di sekolah tersebut.

3. Berdasarkan analisis terbukti bahwa variabel intensitas bermain game online bertema kekerasan berpengaruh secara positif dan signifikan terhadap perilaku agresif siswa di MTs Negeri 8 Sleman. Hal ini berarti bahwa intensitas bermain game online bertema kekerasan suatu madrasah dapat mempengaruhi banyak sedikitnya perilaku agresif siswa di madrasah tersebut.

4. Berdasarkan hipotesis keempat bahwa variabel keharmonisan keluarga, pergaulan teman sebaya, dan intensitas bermain game online bertema kekerasan berpengaruh secara signifikan terhadap perilaku agresif siswa di MTs Negeri 8 Sleman terbukti kebenarannya. Jadi dapat disimpulkan bahwa keharmonisan keluarga, pergaulan teman sebaya, dan intensitas bermain game online bertema kekerasan memiliki pengaruh yang berarti bagi perilaku agresif siswa di MTs Negeri 8 Sleman.

\section{DAFTAR PUSTAKA}

Arikunto, S. 2002. Prosedur Penelitian, Suatu Pendekatan Praktek.Jakarta:PT. Rineka Cipta

Arintina, Y. C dan Fauziah, N. "Keharmonisan Keluarga dan Kecenderungan Berperilaku Agresif pada Siswa SMK”. Tesis. Jurnal Empati, Januari 2015, Vol. 4 (1), hal. 208-212.

Ali, M. danAsrori, M. 2004. Psikologi Remaja (Perkembangan Peserta Didik). Jakarta:PT BumiAksara

Aliaswastika. Remaja Perempuan dan Seksualitas. http://aliaswastika.multiply.com/ reviews/item/11, 2006

Abdullah Bin Muhammad Bin Abdurrahman Bin Ishaq Alu Syaikh. Tafsir Ibnu Katsir Jilid 6 \&8. Pustaka Imam Asy-Syafi'i, 2007.

Azhar.1997. Pendidikan Seks Bagi Remaja Menurut Hukum Islam.Yogyakarta: Mitra Pustaka 
Brantas.2009. Dasar-Dasar Manajemen. Bandung: Alfabeta 